\title{
Effect of Compaction on Compressive Strength of Unfired Clay Blocks
}

\author{
NAWAB ALI LAKHO*, MUHAMMAD AUCHAR ZARDARI*, AND ASHFAQUE AHMED PATHAN** \\ RECEIVED ON 25.01.2016 ACCEPTED ON 11.05.2016 \\ ABSTRACT
}

This study investigates the possible use of unfired compacted clay blocks as a substitute of CSEB (Compressed Stabilized Earth Blocks) for the construction of economical houses. Cubes of $150 \mathrm{~mm}$ size were cut from the clay blocks which were compacted at various intensities of pressure during the casting. The results show that the compressive strength of the clay cubes increased with the compacting pressure to which the blocks were subjected during casting. The average crushing strength of the cubes, sawed from clay blocks that were subjected to compacting pressure of 7.2 MPa, was found to be 4.4 MPa. This value of compressive strength is about $50 \%$ more than that of normal CSEB. This study shows that the compacted clay blocks could be used as economical walling material as replacement of CSEB.

Key Words: Compacted Clay Blocks, Compressive Strength, Density, Compacting Pressure, Mechanized System.

\section{INTRODUCTION}

G enerally, the provision of houses to continuously growing population in many developing countries has always remained a challenge due to lack in GNP (Gross National Product) and rise of cost of traditional materials of construction such as cement, aggregates and steel. The solution of this problem lies in technical use of indigenous and low cost materials of construction.

Clay is used as CSEB and rammed earth. Generally, the CSEB consists of 6-10\% of OPC (Ordinary Portland Cement), $40-70 \%$ of aggregates, $30-60 \%$ of natural indigenous clay and about $10 \%$ water. After mixing it is compacted to increase its density and is cured for 28 days [1] before using in masonry of walls. In this method, individual units are manufactured and stored to use as low cost material for construction of walls. But rammed earth consists of mixture of clay, silt, sand, organic fiber such as chopped straw and water. Generally, OPC is added as binding material with or without lime. This moist loam mixture is used directly at site in formwork and compacted after casting in the shape of walls. The use of rammed earth is as old as 4000 years and is found in China. Even today, rammed earth houses exist and are in use in Russia, Spain, and England [2].

Both of these types of earthen construction have some drawbacks because they require aggregates and cement which are costly. Since cement is produced industrially and results in the emission of carbon dioxide that can

* Department of Civil Engineering, Quaid-e-Awam University of Engineering, Science \& Technology, Nawabshah.

** Department of Civil Engineering, Mehran University of Engineering \& Technology, Jamshoro.

Mehran University Research Journal of Engineering \& Technology, Volume 35, No. 4, October, 2016 [p-ISSN: 0254-7821, e-ISSN: 2413-7219] 
affect the environment on one hand and use electricity or fossil fuel for its production on other [3-4]. Since aggregates and cement are costly on one hand and require higher transportation charges to supply them in the plains of the country. Hence, the use of the CSEB is considered to be neither economical nor environmentally friendly. As far as rammed earth is concerned, it is composed of cement as binding material, and aggregates as stabilizer water. Rammed earth walls on drying, may get cracked due to shrinkage causing weakness at several sections [5-19]. The objective of this study is to investigate potential use of compacted clay-pit sand blocks as replacement of CSEB and rammed earth in order to reduce construction cost and promote sustainable construction of houses without losing strength and durability.

\section{MATERIALS AND METHOD}

Indigenous clay was quarried from the premises of Nawabshah city. The index properties of this local clay [20] are given in Table 1.The pit sand was also quarried locally and it has a moisture content of about 8\%. Local clay and pit sand were mixed in a ratio of $70: 30$ and then $22 \%$ of potable water was added by weight [21], the mixture was thoroughly mixed in pan mixture (Fig. 1). This moist clay pit sand mixture was wrapped in plastic sheet for twenty four hours for proper maturing. For casting of clay blocks, the mix was put in layers in the steel mould (Fig. 2). The size of the mould was 150x400x1980 mm. The size of the blocks cast in this mould was $150 \times 300 \times 1980 \mathrm{~mm}$ which is comparatively larger than the size of traditional CSEB. The mixture of clay and pit sand placed in the mould was pressed with the help of wooden plunger which was flexibly attached to assembly of four hydraulic jacks in the Mechanized System [22] as shown in Fig. 3.
After casting, the blocks were placed in shade for drying (Fig. 4). During this period of drying, clay blocks were placed on wooden planks. In order to reduce the possibility of cracking at bottom, a finished steel plate and two plastic sheets were provided between moist clay block and wooden plank. These moist clay blocks were covered with plastic sheet in order to control the surface cracking of the blocks due to uncontrolled evaporation of moisture. After drying in shade, the clay blocks, were further dried in sun for 48 hours in order to reduce moisture content. After sun drying of these blocks (Fig. 5), cubes of standard $150 \mathrm{~mm}$ size [23] were sawed with the help of disk grinder machine (Fig. 6) and tested in UTM (Universal Testing Machine) (Fig. 7). Eighteen cubes were cut and tested in compression.

\section{RESULTS AND DISCUSSION}

It was mentioned earlier that $22 \%$ of water was added in the clay pit sand mixture in order to make the mix workable

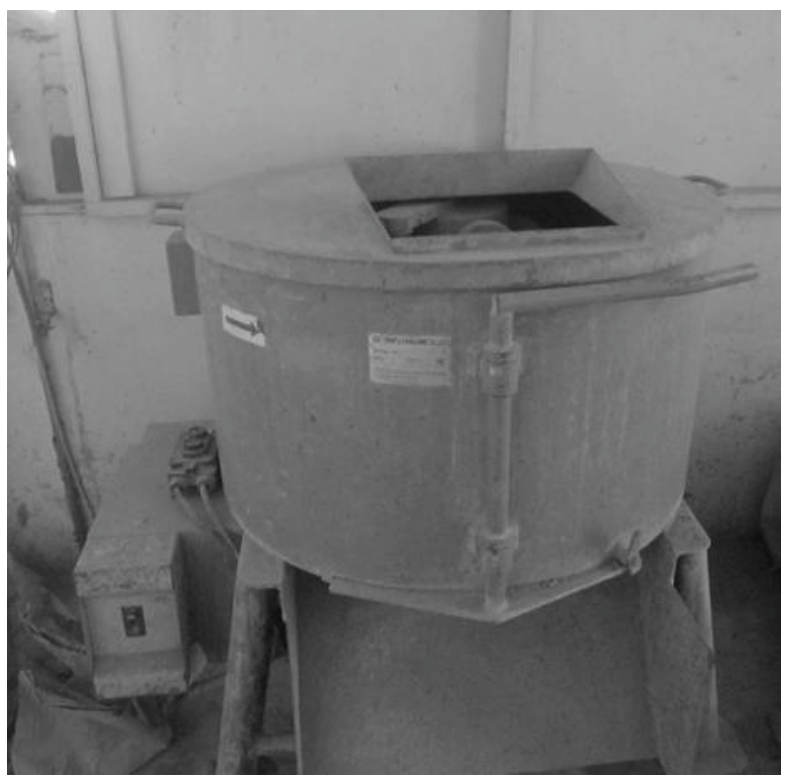

FIG. 1. PAN MIXER USED FOR MIXING OF CLAY PIT SAND AND WATER

TABLE 1. INDEX PROPERTIES OF INDIGENOUS CLAY [20]

\begin{tabular}{|c|c|c|c|c|c|c|}
\hline $\begin{array}{c}\text { Moisture Content } \\
(\%)\end{array}$ & $\begin{array}{c}\text { Specific } \\
\text { Gravity }\end{array}$ & $\begin{array}{c}\text { Liquid Limit } \\
(\%)\end{array}$ & $\begin{array}{c}\text { Plastic Limit } \\
(\%)\end{array}$ & Plasticity Index & $\begin{array}{c}\text { Density of Wet Soil } \\
\left(\mathrm{g} / \mathrm{cm}^{3}\right)\end{array}$ & $\begin{array}{c}\text { Density of Dry Soil } \\
\left(\mathrm{g} / \mathrm{cm}^{3}\right)\end{array}$ \\
\hline 12 & 2.5 & 44 & 23 & 21 & 1.5 & 1.3 \\
\hline
\end{tabular}

Mehran University Research Journal of Engineering \& Technology, Volume 35, No. 4, October, 2016 [p-ISSN: 0254-7821, e-ISSN: 2413-7219] 
for casting of blocks. Standard proctor compaction tests were carried out in order to determine the optimum water content of the indigenous clay and pit sand mixture to determine maximum dry density (Fig. 8). It can be observed that the optimum moisture content of the indigenous clay pit sand mixture was found to be $12 \%$. To reduce the added quantity of mixing water, the clay blocks were enveloped in propylene fabric sheet and compacted with the help of plunger of the mechanized system. In this way, the added water in the clay blocks was pressurized to drain out. Consequently, the mixed water was reduced from $22-13 \%$ which is close to the optimum water content (i.e. 12\%) of the clay pit sand mixture.

The effect of compaction, during casting process of clay blocks, on the compressive strength of cubes of $150 \mathrm{~mm}$ size is presented in Fig. 9. It can be observed that, as expected, the compressive strength of clay cubes increased with the increase of intensity of compacting pressure during casting. The increase in

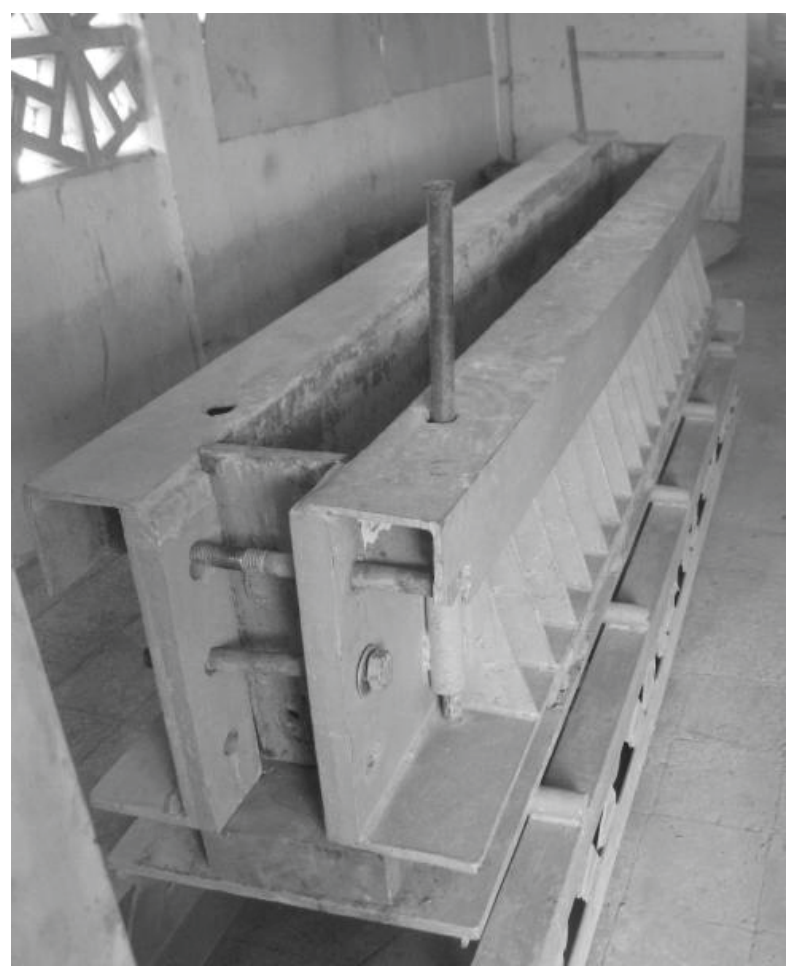

FIG. 2. MOULD FOR CASTING OF CLAY BLOCKS compressive strength of clay cubes is associated with the reduction of voids due to expulsion of water from mass of moist clay and as a result, the clay blocks became denser. It is relevant to mention here that the compressive strength of CSEB is generally in the range

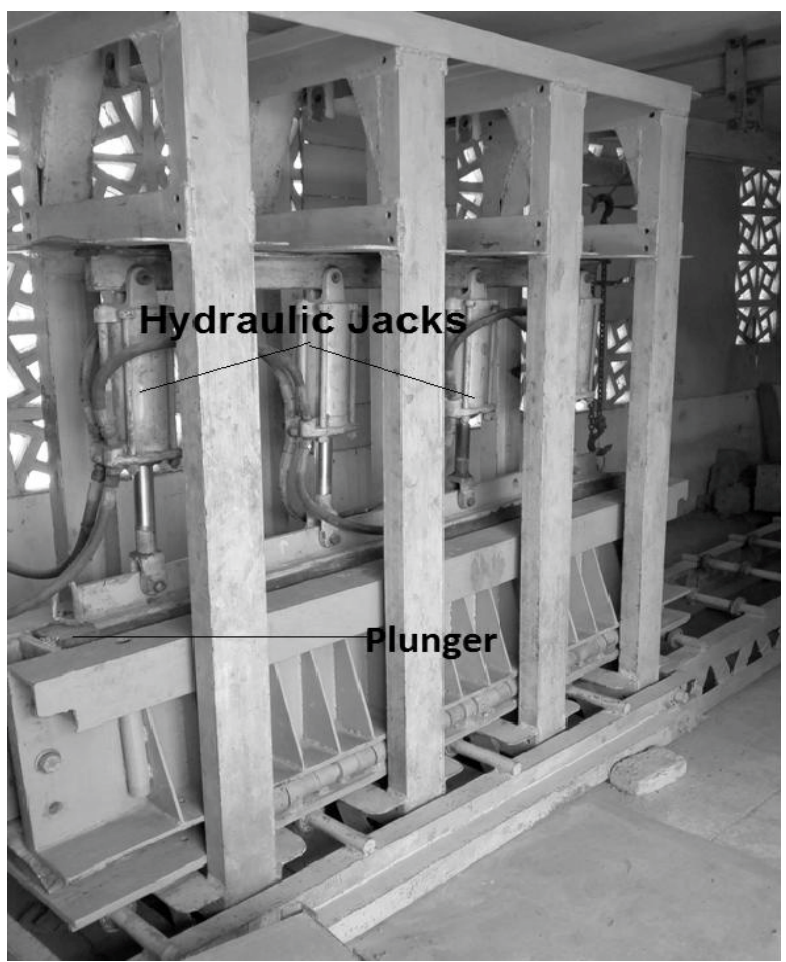

FIG. 3. MOIST CLAY-PIT SAND MIXTURE PLACED IN LAYERS IS BEING COMPACTED WITH THE WOODEN PLUNGER OF THE MECHANIZED SYSTEM

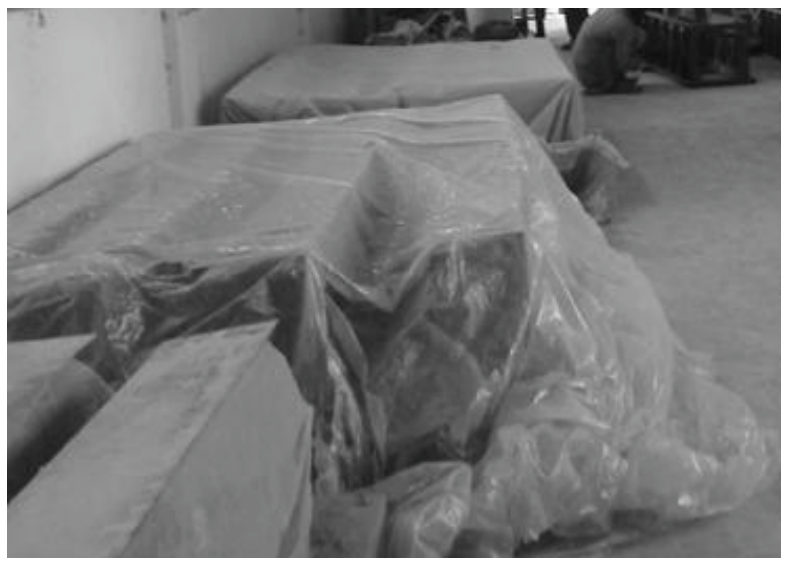

FIG. 4. MOIST CLAY BLOCKS WRAPPED WITH PLASTIC SHEET COVER ARE BEING DRIED IN SHADE

Mehran University Research Journal of Engineering \& Technology, Volume 35, No. 4, October, 2016 [p-ISSN: 0254-7821, e-ISSN: 2413-7219] 
of 2-2.5 $\mathrm{MPa}$ [24]. The average compressive strength of clay blocks presented in this study was $4.4 \mathrm{MPa}$ which is about $50 \%$ more than that of the CSEB. This

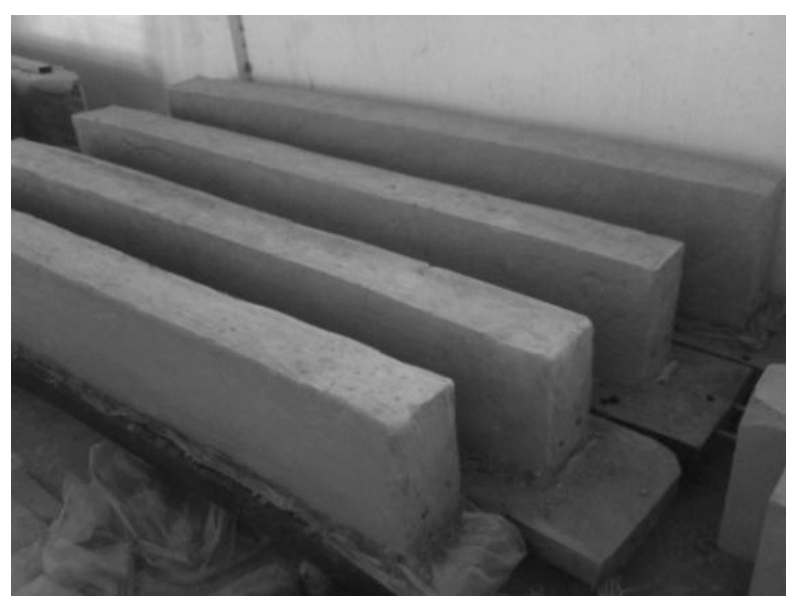

FIG. 5. A VIEW OF SUN-DRIED CLAY BLOCKS

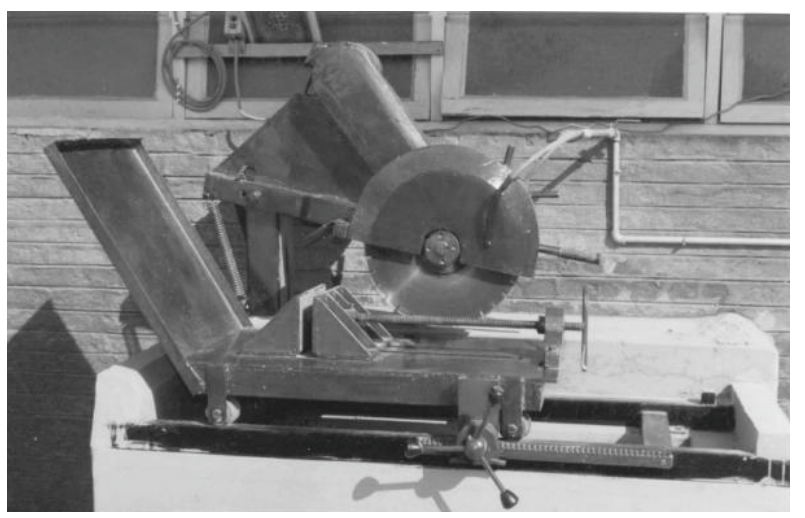

FIG. 6. A VIEW OF DISK GRINDER MACHINE FOR CUTTING CUBES FROM CLAY BEAMS implies that the compacted clay blocks can be used as walling material as an alternative to the CSEB for construction of low cost houses.

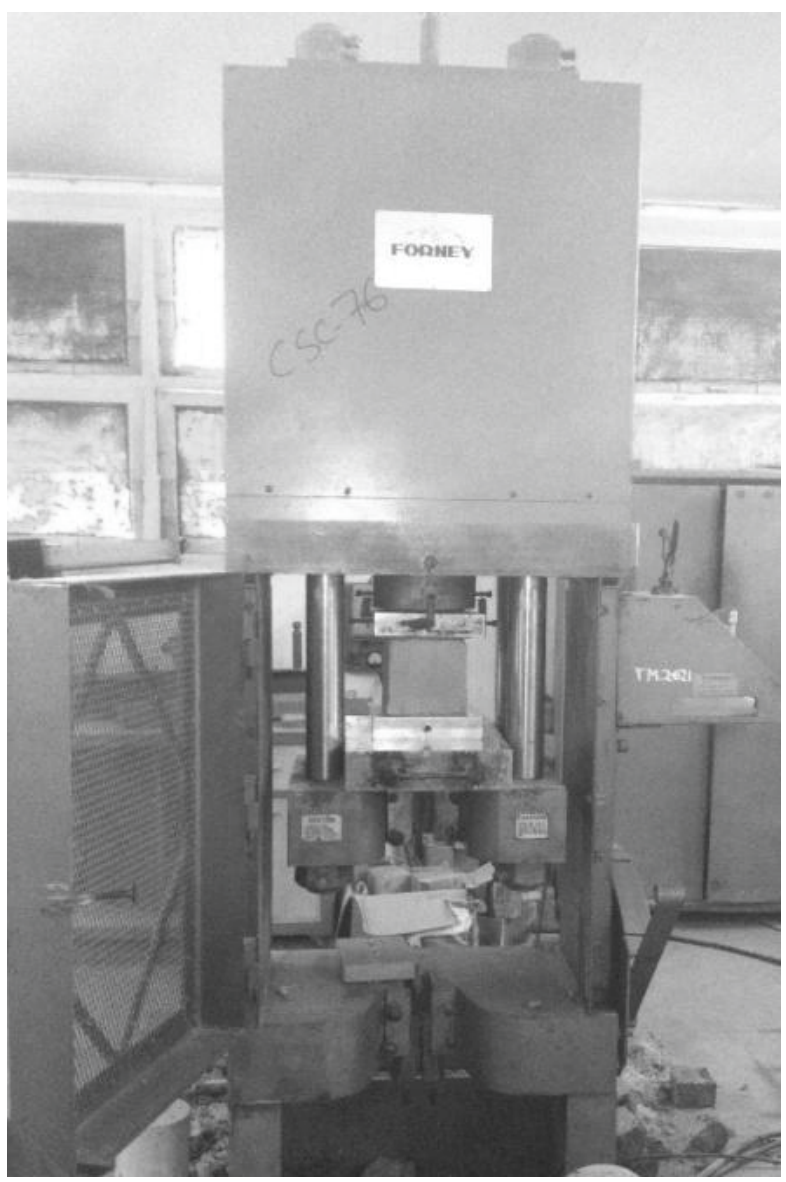

FIG. 7. A VIEW OF COMPACTED CLAY CUBE BEING TESTED IN UNIVERSAL TESTING MACHINE

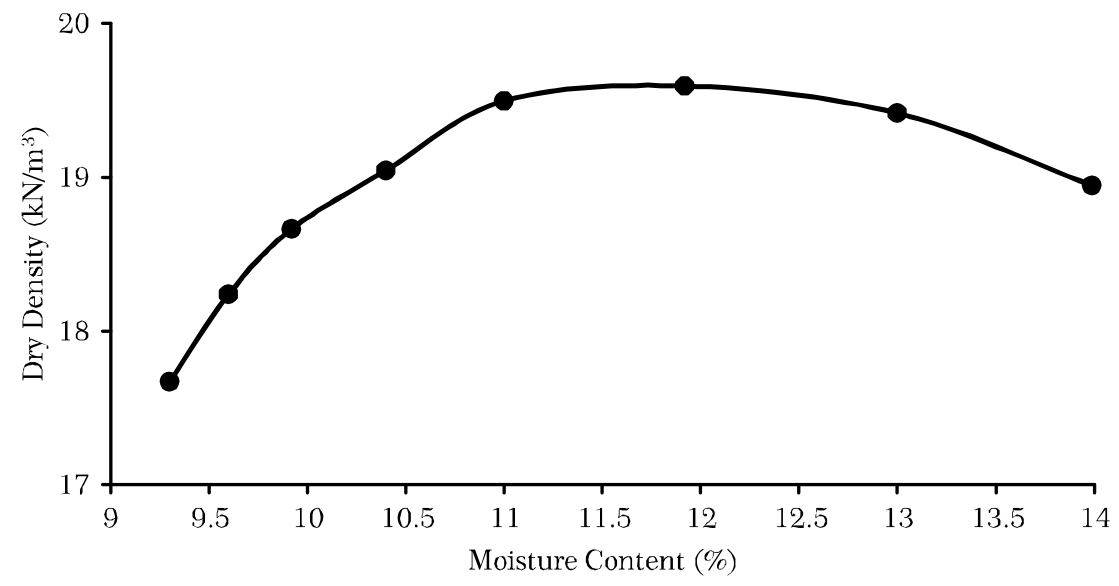

FIG. 8. RELATIONSHIP BETWEEN WATER CONTENT AND DRY DENSITY OF THE INDIGENOUS CLAY USED FOR CASTING OF BLOCKS 


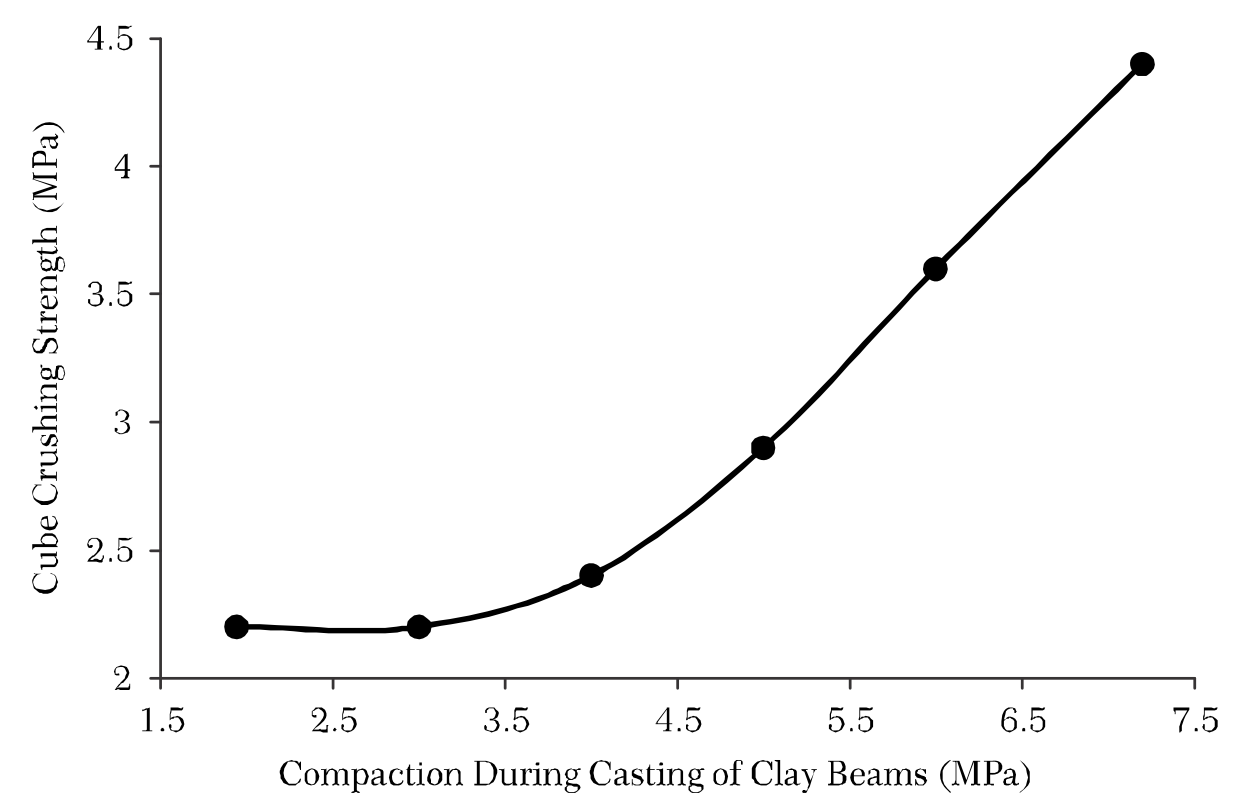

FIG. 9. RELATIONSHIP BETWEEN COMPACTING PRESSURES APPLIED DURING CASTING OF CLAY BLOCKS AND CUBE CRUSHING STRENGTH

\section{CONCLUSIONS}

In this paper cube crushing strength of unfired clay, which was subjected to varying intensities of compacting pressure during casting process, was investigated. Cubes of $150 \mathrm{~mm}$ size were tested for compressive strength. Main conclusions drawn from this study are:

(i) The compressive strength of clay cubes increased with increase of compacting pressure that was applied during the process of casting of the blocks.

(ii) The cubes cut from clay blocks that were compacted at a pressure of 7.2 $\mathrm{MPa}$, showed compressive strength of 4.4 MPa.

(iii) This study shows that the compressive strength of cubes obtained was $50 \%$ more than that of the CSEB. This is a significant achievement because by using unfired clay will result in economical construction of houses as compared to the CSEB.

\section{ACKNOWLEDGEMENTS}

The tests were performed at the Structural Engineering Laboratory of Quaid-e-Awam University of Engineering, Science \& Technology Nawabshah, and Mehran University of Engineering \& Technology, Jamshoro, Pakistan. This support is gratefully acknowledged.

\section{REFERENCES}

[1] Krosnowski, A.D., “A Proposed Best Practice Method of Defining a Standard of Care for Stabilized Compressed Earthen Block Production”, Doctoral Dissertation, Architectural Engineering, University of Colorado at Boulder, 2011.

[2] Minke, G., "Building with Earth: Design and Technology of a Sustainable Architecture”, Walter de Gruyter, 2012.

[3] Gartner, E. "Industrially Interesting Approaches to Low$\mathrm{CO}_{2}$ Cements”, Cement and Concrete Research, Volume 34, No. 9, pp. 1489-1498, 2004.

[4] Damtoft, J.S., Lukasik, J., Herfort, D., Sorrentino, D., and Gartner, E.M,. "Sustainable Development and Climate Change Initiatives”, Cement and Concrete Research, Volume 38, No. 2, pp. 115-127, 2008. 
[5] Jayasinghe, C., and Kamaladasa, N., "Compressive Strength Characteristics of Cement Stabilized Rammed Earth Walls”, Construction and Building Materials, Volume 21, No. 11, pp. 1971-1976, 2007.

[6] Galán-Marín, C., Rivera-Gómez, C., and Petric, J., “ClayBased Composite Stabilized with Natural Polymer and Fiber”, Construction and Building Materials, Volume 24, No. 8, pp. 1462-1468, 2010.

Burroughs, S., "Soil Property Criteria for Rammed Earth Stabilization”, Journal of Materials in Civil Engineering, Volume 20, No. 3, pp. 264-273, 2008.

Bahar, R., Benazzoug, M., and Kenai, S., "Performance of Compacted Cement-Stabilized Soil”, Cement and Concrete Composites, Volume 26, No. 7, pp. 811-820, 2004.

Kouakou, C.H., and Morel, J.C., "Strength and ElastoPlastic Properties of Non-Industrial Building Materials Manufactured with Clay as a Natural Binder”, Applied Clay Science, Volume 44, No. 1, pp. 27-34, 2009.

[10] Reddy, B.V., and Kumar, P.P., "Cement Stabilized Rammed Earth, Part-A: Compaction Characteristics and Physical Properties of Compacted Cement Stabilized Soils”, Materials and structures, Volume 44, No. 3, pp. 681-693, 2011.

[11] Maniatidis, V., and Walker, P., "Structural Capacity of Rammed Earth in Compression”, Journal of Materials in Civil Engineering, Volume 20, No. 3, pp. 230-238, 2008.

[12] Bui, Q.B., and Morel, J.C., "Assessing the Anisotropy of Rammed Earth”, Construction and Building Materials, Volume 23, No. 9, pp. 3005-3011, 2009.

[13] Delgado, M.C.J., and Guerrero, I.C., "Earth building in Spain”, Construction and Building Materials, Volume 20, No. 9, pp. 679-690, 2006.

[14] Bui, Q.B., Morel, J.C., Hans, S., and Meunier, N., "Compression Behaviour of Non-Industrial Materials in Civil Engineering by Three Scale Experiments: The Case of Rammed Earth", Materials and Structures, Volume 42, No. 8, pp. 1101-1116, 2009.
[15] Easton, D., “The Rammed Earth House”, Chelsea Green Publishing, 2007.

[16] Delgado, M.C.J., and Guerrero, I.C., "The Selection of Soils for Unsterilized Earth Building: A Normative Review", Construction and Building Materials, Volume 21, No. 2, pp. 237-251, 2007.

Keable, R., Martin, J., and Maniatidis, V., "Rammed Earth: Design and Construction Guidelines”, Watford: BRE Bookshop, 2005.

[18] Keefe, L., "Earth Building: Methods and Materials, Repair and Conservation”, Routledge, 2012.

[19] Joffroy, T., and Odul, P., "Compressed Earth Blocks: Manual of Design and Construction”, Vieweg, 1995.

[20] Ansari, A.A., "Experimental Study of the Behavior of Pre-Perforated Post-Reinforced Baked Clay Panels of Beams”, Ph.D. Thesis, Quaid-e-Awam University of Engineering, Science \& Technology, Nawabshah, Pakistan, 2008.

[21] Memon, M., Ansari, A.A., and Shaikh. A.M., "Preliminary Study of Structural Properties of Baked Clay”, Mehran University Research Journal of Engineering \& Technology, Volume 18, No. 3, pp. 161-166, Jamshoro, Pakistan, July, 1999.

[22] Lakho, N.A., Zardari, M.A., Memon, M., and Saand, A., "Design and Fabrication of Mechanized System for Casting and Compacting Laboratory Size Clay Beams”, Scientia Iranica, Volume 22, No. 6, pp. 2046-2051, 2015.

[23] BSEN 12390-3, "Testing Hardened Concrete - Part-3: Compressive Strength of Test Specimens”, 2002.

[24] Guillaud, H., Joffroy, T., Odul, P., and Eag, C., "Compressed Earth Blocks: Manual of Design and Construction”, A Publication of the Deutsches Zentrumfür Entwicklungstechnologien - GATE, 1985. 